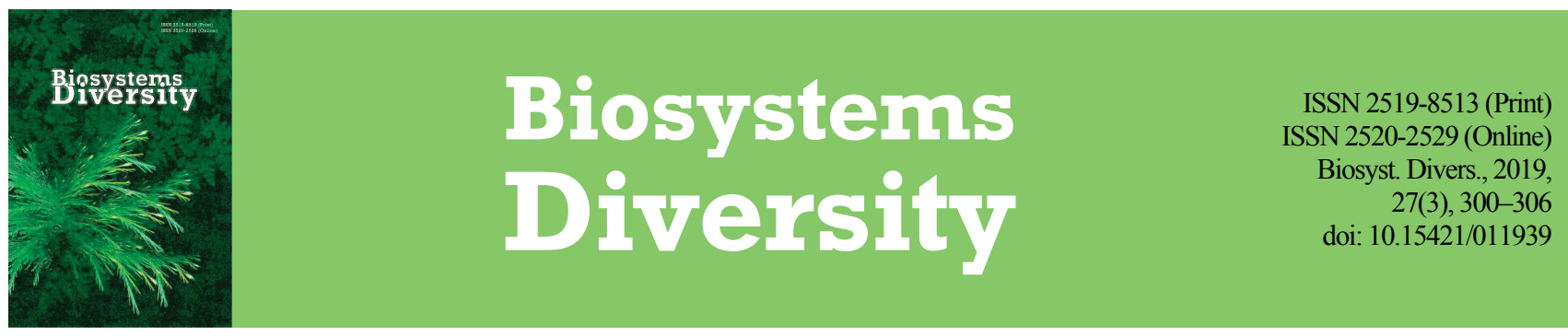

\title{
Bactericidal, protistocidal, nematodicidal properties and chemical composition of ethanol extract of Punica granatum peel
}

\author{
V. A. Palchykov, V. V. Zazharskyi, V. V. Brygadyrenko, P. O. Davydenko, \\ O. M. Kulishenko, I. V. Borovik, V. Chumak, A. Kryvaya, O. O. Boyko \\ *Dnipro State Agrarian and Economic University, Dnipro, Ukraine \\ **Oles Honchar Dnipro National University, Dnipro, Ukraine
}

Article info

Received 06.07.2019

Received in revised form 11.082019

Accepted 12.08.2019

Dnipro State Agrarian and Economic University Sergiy Efremov st., 25 , Dnipro, 49000, Ukraine. Tel.: + 38-056-713-51-74 E-mail:

zazharskiy»@gmail.com

Oles Honchar Dnipro National University,

Gagarin av., 72,

Dnipro, 49010, Ukraine.

Tel.: +38-050-939-07-88

E-mail:brigad@ua.fm

Palchykov, V. A., Zazharskyi, V. V., Brygadyrenko, V. V., Davydenko, P. O., Kulishenko, O. M., Borovik, I. V., Chumak, V., Kryvaya, A., \& Boyko, O. O. (2019). Bactericidal, protistocidal, nematodicidal properties and chemical composition of ethanol extract of Punica granatum peel. Biosystems Diversity, 27(3), 300-306. doi:10.15421/011939

We have studied the chemical composition and antibacterial profile of ethanolic extract of Punica granatum L. (Lythraceae) on strains of microorganisms in vitro. Analysis using GC-MS showed 5-hydroxymethylfurfural (36.6\%), D-sucrose (23.2\%), sorbitol $(6.7 \%)$, palmitic acid $\beta$-monoglyceride $(5.6 \%)$, 2-furancarboxaldehyde $(3.5 \%)$ and $\beta$-D-glucopyranose $(3.3 \%)$ as the major components of the title extract. The experiment revealed a positive antibacterial effect of extracts obtained from P. granatum on 14 strains specifically Enterobacteriaceae microorganisms (Escherichia coli, Enterobacter aegorenes, Proteus vulgaris, Serratia marcescens, Klebsiella pneumonia), Listeriaceae (Listeria ivanovi, L. innocua, L. monocytogenes) and yeasts from the family Saccharomycetaceae (Candida albicans). Our study showed that in many cases these extracts more intensively affect multi-resistant strains of microorganisms than macrolide antibiotic azithromycin and is therefore a source of molecules to be exploited in medicine or by the pharmaceutical industry. The investigated extracts of $P$. granatum can be recommended for further in-depth research against poly-resistant strains of the above-mentioned microorganisms. Effective drugs perform a leading role in providing stable veterinary well-being of livestock and healthcare of the population. The present study showed that the studied plant species more intensively affects multi-resistant strains of microorganisms than sodium salt of azithromycin. Lethal concentration $\left(\mathrm{LC}_{50}\right)$ of ethanol extract from pomegranate for Paramecium caudatum Ehr. equaled $0.3 \%$. Death of $100 \%$ of nematode larvae of Strongyloides papillosus (Ihle) was recorded during $24 \mathrm{~h}$ exposition in $20 \%$ extract of $P$. granatum peel.

Keywords: Pomegranate; bactericidal action; gas chromatography-mass spectrometry (GC-MS); 5-hydroxymethylfurfural; D-sucrose; sorbitol.

\section{Introduction}

Pomegranate (Punica granatum L.) is a perennial fruit tree that originated in the Mediterranean region and is now cultivated worldwide. In the United States, commercial production of pomegranates is almost exclusively confined to California. Punica granatum and its evolutionnary precursor $P$. protopunica Balf. (also known as the Socotran pomegranate) are the only two members of genus Punica (Holland et al., 2009). Pomegranate a long-established fruit in folk medicine (Schubert et al., 1999; Mehdi Talebi et al., 2018), has a protective and therapeutic effect in diseases such as coronary heart disease, arthritis, Alzheimer's disease, diabetes, obesity, cancer, infertility (Frawley, 1986; Cáceres et al., 1987; Schubert et al., 1999; Saxena \& Vikram, 2004; Lansky \& Newman, 2007). In addition to being a religious symbol and a culinary delight, the pomegranate's bark, roots, fruit peel, aril (juice sac covering the seed; sometimes used as a collective name for juice and seed), and seeds, have been used for medicinal purposes since ancient times. Several classes of natural product compounds have been identified from various pomegranate tissues, including phenolics, terpenoids, alkaloids and fatty acids/triglycerides, many of which account for the bioactivities of pomegranate constituents (Seeram et al., 2006). In addition, studies have shown the presence of antioxidants, such as steroids, flavonoids, polyphenols, saponins, alkaloids, triterpenoids and vitamin $\mathrm{C}$ in various extractions from whole fruits, juice, peel and pomegranate seeds (Bhandary et al., 2012)

Nuamsetti et al. (2012) also mentioned the effectiveness of extracts from $P$. granatum due to content of high levels of phenolics and exhibited antibacterial activity against all bacteria tested (Bacillus subtilis, Sta- phylococcus aureus, Escherichia coli, and Salmonella typhimurium). Gram-positive bacteria were more sensitive to the extracts than Gramnegative ones. Pomegranate peel contains substantial amounts of polyphenols such as ellagic tannins, ellagic acid, and gallic acid (Negi et al., 2003). Kaur et al. (2006) found that the ethanol extract of pomegranate flowers contains a large amount of polyphenols and has a huge regenerating ability, which indicates a strong $(81.6 \%)$ antioxidant capacity in the DPPH model system. Schubert et al. (1999) and Faisi et al. (2018) argue that the polyphenolic fraction of pomegranate juice can act as an anti-atherogenic supplement and natural preservative for meat and fatty foods by directly inhibiting the oxidation of LDL.

According to Mehru et al. (2008), methanol extract from peel of $P$. granatum exerted antimicrobial activity against enteropathogenic bacteria (Escherichia coli, Salmonella typhi, Shigella dysenteriae) with MIC equaling $12.5 \mathrm{mg} / \mathrm{mL}$. The extract was tested on Artemia salina brine shrimps, but no reliable toxicity was observed, as $\mathrm{LC}_{50}$ equaled $1.42 \mathrm{mg} / \mathrm{mL}$, and preparations are considered toxic when they affect the shrimps in concentrations below $1 \mathrm{mg} / \mathrm{mL}$.

In the literature one can regularly find data on the impact of aqueous and ethanol extracts of medical plants on the nematodes of different agricultural animals of different stages of the development (Rahmann et al., 2006; Burke et al., 2009; Lu et al., 2010; Ferreira et al., 2011; Boyko \& Brygadyrenko, 2016). The effect of extracts from P. granatum on S. papillosus larvae is currently unstudied. Jahromi et al. (2015) studied the safety of the extract of pomegranade peel for mice. Doses of 0.5, 1.9 and $7.5 \mathrm{mg} / \mathrm{kg}$ of body weight introduced over 22 days displayed no toxic effect according to clinical signs and histopreparations. 
Patel et al. (2008) determined no-observed-adverse-effect level (NOAEL) for standardized extract from fruits of pomegranate in dose up to $600 \mathrm{mg} / \mathrm{kg}$ of body weight a day, which is the highest tested dose. The extract was standardized according to punicalagins, the main phenols of $P$. granatum responsible for its antioxidant potential. Subchronic study on rats was carried out using a probe of 60,240 and $600 \mathrm{mg} / \mathrm{kg}$ of body weight daily over 90 days.

During testing ethanol extract from fruits and seeds of $P$. granatum on white mice, Satheesh Kumar Bhandary et al. (2013) observed no death or changes in behaviour, impairments in parameters of blood and histological deviations in the liver and kidneys (the authors used extracts with internal administration by $2 \mathrm{~g} / \mathrm{kg}$ of body weight daily over 28 days). Ethanol extract from seeds of $P$. granatum had no sharp systemic toxicity at consumption by mice in the dose of over $160 \mathrm{mg} / \mathrm{kg}$ of body weight during 7 days observation (Setiadhi et al., 2017).

Therefore, it is practical to conduct complex in vitro study on the antibacterial effect of ethanol extracts of $P$. granatum on strains of microorganisms of Enterobacteriaceae, Pseudomonadaceae, Staphylococcaceae, Bacillaceae, Listeriaceae, Corynebacteriaceae and Saccharomycetaceae families, as well as Paramecium caudatum and nematode larvae of Strongyloides papillosus Wedl, 1956, parasites of the gastrointestinal tract of ruminants and rabbits.

\section{Materials and methods}

Gas chromatography-mass spectrometry $(G C-M S)$ analysis of Punica granatum crude extract. The GC-MS analysis of volatile components of extract was carried out on a Shimadzu GCMS-QP2010 mass spectrometer equipped with a Restek Rxi-5ms (Crossbond ${ }^{\mathbb{B}} 5 \%$ diphenyl $/ 95 \%$ dimethyl polysiloxane) column (length $30 \mathrm{~m}$, diameter $0.25 \mathrm{~mm}$, thickness $0.25 \mu \mathrm{m}$ ) under the following conditions. The oven temperature was programmed from 50 to $300{ }^{\circ} \mathrm{C}$ at $10^{\circ} \mathrm{C} / \mathrm{min}$, then held isothermally at $300^{\circ} \mathrm{C}$ for $20 \mathrm{~min}$ (total GC time $45 \mathrm{~min}$, solvent cut time $2.5 \mathrm{~min}$ ). The injector temperature, interface temperature and ion source temperature were maintained at 250,250 and $220^{\circ} \mathrm{C}$, respectively. The sample $(1.0 \mu \mathrm{L})$ was injected manually in the split mode at a ratio of 1:50 using helium ( $99.996 \%$ purity) as carrier gas at $1.0 \mathrm{~mL} / \mathrm{min}$ (pressure $53.5 \mathrm{kPa}$ ). Mass spectra were acquired over the range of $\mathrm{m} / \mathrm{z}$ 25 to 500 using electron impact ionization $(70 \mathrm{eV})$. The essential constituents were identified by comparing their mass spectra reported in the NIST (National Institute of Standards and Technology) mass spectral library (2014). We have taken into account only the strong levels of similarity of MS spectra more than $75 \%$. Component relative percentages were calculated based on GC peak TIC areas without calculating the detector response factor.

Antibacterial activity of extract of $P$. granatum peel was determined by the method of agar disc diffusion. A suspension was prepared from a daily culture of reference cryogenic strains of 14 microorganisms according to the turbidity standard of a bacterial suspension of 0.5 units according to Mac Farland $1.5 \times 10^{8} \mathrm{CFU}$, which was determined using Densimeter II. The resulting suspension was subcultured on Müller-Hinton agar (Himedia), followed by cultivation in a TCO-80/1 thermostat for 24 and 48 hours at $37^{\circ} \mathrm{C}$. After the time necessary for the cultivation of the studied microorganisms, we assessed the number of the microorganisms that grew in the Petri dish. The cultivated colonies underwent microscopy. If necessary, an additional identification of microorganisms was conducted in accordance with EN ISO 11133:2014, IDT.

Discs with $15.0 \mu \mathrm{g}$ azithromycin served as positive control (Valle et al., 2015). Azithromycin is a white crystalline powder. It is a broadspectrum antibiotic; antibiotic-azalide, a representative of a new subgroup of macrolide antibiotics. Discs with $15.0 \mu \mathrm{g}$ amphotericinin were also used as a second control against Candida albicans.

After 24 and 48 hours of incubation, the diameter of the culture growth inhibition zone was measured using the template for measuring the size of microorganism growth inhibition zones (Antibiotic Zone ScaleC, model PW297, India) and TpsDig2 program (2016, F. James Rohlf).

An analysis of the extract of pomegranate on $P$. caudatum was performed according to the generally accepted methods (Kotsumbas et al., 2006; Zazharskyi et al., 2018). Cultivation of $P$. caudatum was carried out in lactic media. The culture was maintained at the room temperature $\left(+18 \ldots+20^{\circ} \mathrm{C}\right)$. For the biotesting, we used $24 \mathrm{~h}$ culture which was in the phase of exponential (active) growth. For conducting toxicologic study, a series of dilutions of extract of pomegranate measuring $0.05 \%$, $0.10 \%, 0.20 \%, 0.50 \%$ and $1.00 \%$ was prepared. Into the micro-aquarium cavities (here micro-aquarium cavity is understood as a $20 \mu \mathrm{L}$ depression in a microscope slide), $20 \mu \mathrm{L}$ of media with ciliates (10-20 individuals) were added. Then $20 \mu \mathrm{L}$ of aqueous solution of the studied preparation of different concentration were added to each of the capacities, and the number of ciliates in the mixture was counted. After an hour's exposure, the number of $P$. caudatum in each micro-aquarium was counted again for assessing the level of their survival.

The larvae of nematodes Strongyloides papillosus Wedl, 1956 in feces of ruminants were found using the Baermann test (Zajac et al., 2011) Then, $1 \mathrm{~mL}$ of the extract of $P$. granatum in different concentrations $(1 \%, 5 \%, 10 \%, 15 \%, 20 \%, 25 \%)$ was added to each culture of S. papillosus nematode larvae (in five replications). The experimental exposure equaled 24 hours. We determined the number of vital and dead larvae.

Data on acute toxicity of the studied concentrations of the pomegranate extract were obtained in accordance with the recommended methods of express-biotesting. Value of $\mathrm{LC}_{50}$ for ciliates was determined using probit-analysis of curves of lethality (Recommendations of OECD Guidelines for the Testing of Chemicals for evaluation of toxic effect of toxicants). The data in the tables are presented in the form $\mathrm{x} \pm \mathrm{SD}$. The differences between the values in the control and experimental groups were determined using the Tukey test, where the differences were considered significant at $\mathrm{P}<0.05$ (taking into account the Bonferroni correction).

\section{Results}

The chemical composition of the volatile part of the $P$. granatum crude extract was analyzed by GC-MS method (Fig. 1). Identified compounds are summarized in Table 1 and structures of major components are depicted in Figure 2. As presented in Table 1, about 15 different components were identified. Major compounds $(>3 \%)$ in the sample are 5-hydroxymethylfurfural (36.6\%), D-sucrose (23.2\%), sorbitol (6.7\%), palmitic acid $\beta$-monoglyceride (5.6\%), 2-furancarboxaldehyde (3.5\%) and $\beta$-D-glucopyranose (3.3\%). These 6 components are representing ca. $79 \%$ of sample in total. Unfortunately, one component in crude extract has not been identified.

We determined the antibacterial effect of the extract from $P$. granatum peels towards Escherichia coli (Table 2): if after 24 hour of exposure it gave a zone of growth inhibition of less than the control by $2.11 \mathrm{~mm}$, then after $48 \mathrm{~h}$ this parameter exceeded the control by $0.83 \mathrm{~mm}$. The zone of inhibition of growth of $P$. vulgaris after $24 \mathrm{~h}$ of exposure in the experimental group was higher than the control by $17.22 \mathrm{~mm}$, and after $48 \mathrm{~h}$ - by $18.44 \mathrm{~mm}$. We observed antibacterial effect of extract from $P$. granatum peels on $S$. marcescens: after $24 \mathrm{~h}$ of cultivation of microorganisms, the zone of inhibition of growth in the experimental group was higher than the control by $5.46 \mathrm{~mm}$, and after $48 \mathrm{~h}-$ by $7.13 \mathrm{~mm}$.

Moderate antibacterial activity was observed against $K$. pneumoniae: it was lower than the control by $3.75 \mathrm{~mm}$ after $24 \mathrm{~h}$, and by $2.42 \mathrm{~mm}$ after two days. Lower effect was demonstrated after impact of extract of $P$. granatum peels on $E$. aegorenes: growth inhibition zone equaled $6.32-8.13 \mathrm{~mm}$, which was lower than the control values. Strains of E. faecalis and S. typhimurium were resistant to the extract of $P$. granatum peels and azithromycin. No effect was exerted by the extract from peels of $P$. granatum against microorganisms of Pseudomonadaceae families: $P$. aeruginosa ATCC $2853(\mathrm{~F})$ and $P$. aeruginosa $27 / 99$ were resistant to the tested extract.

Moderate resistence of $S$. aureus and B. cereus to the tested preparation was observed: the inhibition zone grew by 2.84 and $2.54 \mathrm{~mm}$ respectively, though this parameter was lower than the control by 15.25 and $8.17 \mathrm{~mm}$. High antimicrobial efficiency was displayed against microorganisms of the Listeriaceae family. If the growth inhibition zone of $L$. ivanovi was lower than the control by $3.97 \mathrm{~mm}$ after $48 \mathrm{~h}$, for L. innocua and L. monocytogenes it exceeded control by 1.92 and $7.66 \mathrm{~mm}$ 


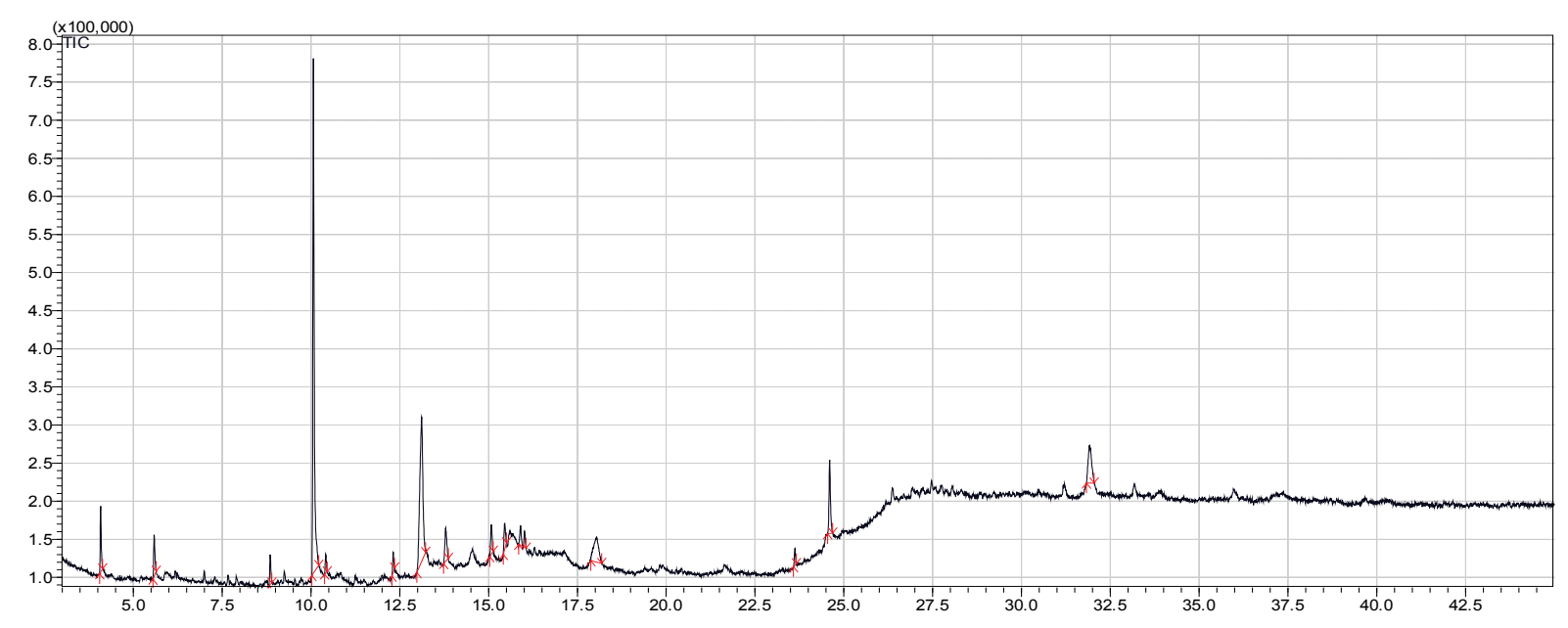

Fig. 1. Total ion current (TIC) chromatogram of the crude ethanol extract of $P$. granatum: abscissa axis $(\mathrm{X})$ is time in minutes, ordinate axis $(\mathrm{Y})$ is signal intensity in relative units)
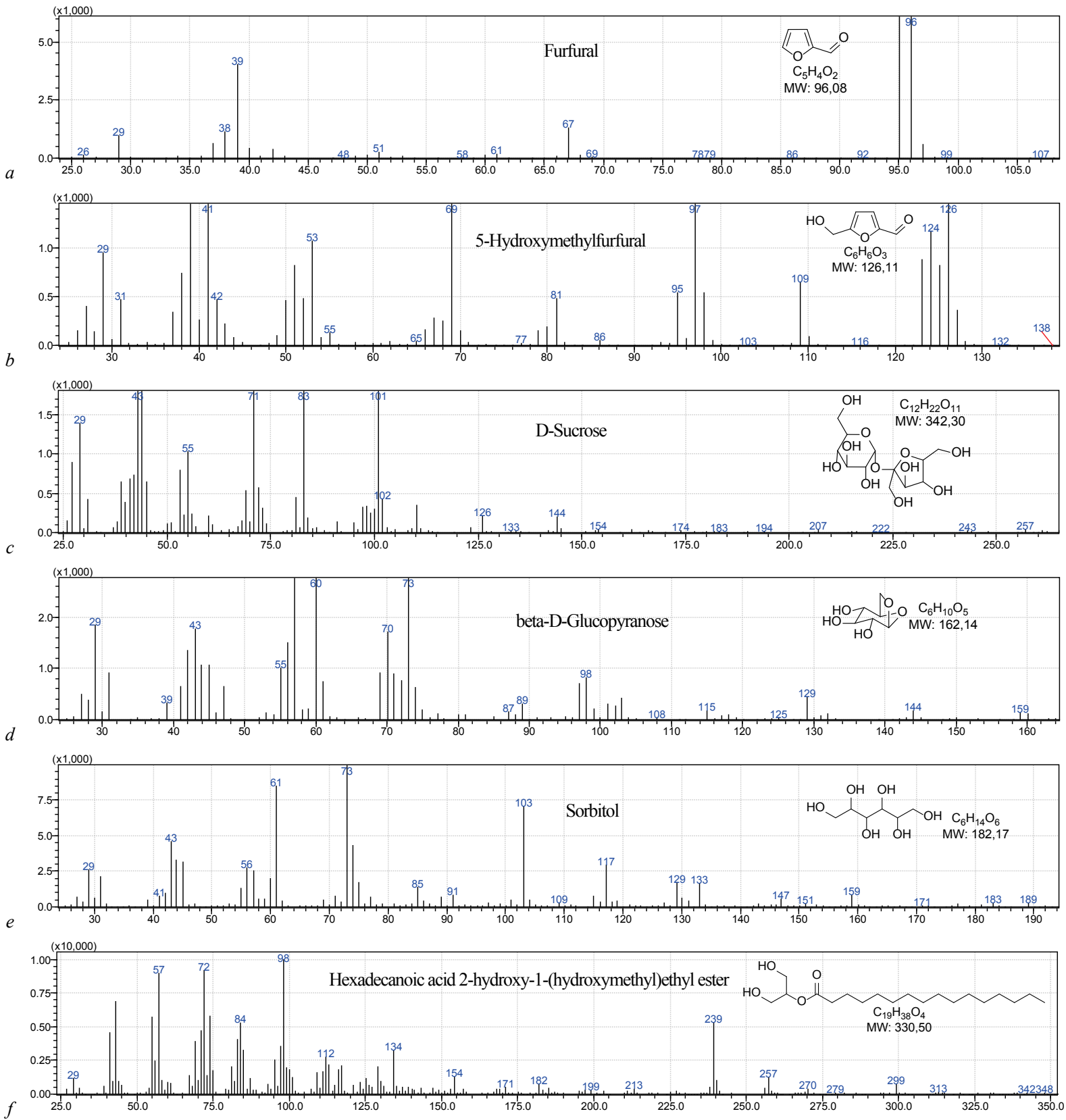

Fig. 2. Major components $a-f(>3 \%$ each) found in the crude ethanol extract of Punica granatum with their experimentally measured MS-spectra: abscissa axis $(\mathrm{X})$ is mass-to-charge ratio $(\mathrm{m} / \mathrm{z})$, ordinate axis $(\mathrm{Y})$ is signal intensity in relative units; molecular weight $(\mathrm{MW})$ is given in Da 
Table 1

Chemical composition of the crude ethanol extract of $P$. granatum by GC-MS method

\begin{tabular}{cclcc}
\hline Entry & $\begin{array}{c}\text { Retention } \\
\text { time, min }\end{array}$ & Compound name (synonyms) & Formula & Area, \% \\
\hline 1 & 4.080 & Furfural (2-Furancarboxaldehyde) & $\mathrm{C}_{5} \mathrm{H}_{4} \mathrm{O}_{2}$ & 3.49 \\
2 & 5.586 & 3-methyl-2,5-furandione (Citraconic anhydride) & $\mathrm{C}_{5} \mathrm{H}_{4} \mathrm{O}_{3}$ & 2.67 \\
3 & 8.854 & 2,3-dihydro-3,5-dihydroxy-6-methyl-4H-pyran-4-one & $\mathrm{C}_{6} \mathrm{H}_{8} \mathrm{O}_{4}$ & 1.75 \\
4 & 10.070 & 5-Hydroxymethylfurfural & $\mathrm{C}_{6} \mathrm{H}_{6} \mathrm{O}_{3}$ & 36.60 \\
5 & 10.416 & 3-hydroxy-2-methyl-4H-pyran-4-one (Maltol, Larixic acid, Larixinic acid) & $\mathrm{C}_{6} \mathrm{H}_{6} \mathrm{O}_{3}$ & 1.14 \\
6 & 12.317 & Succinic acid 3-methylbutyl pentyl ester & $\mathrm{C}_{14} \mathrm{H}_{26} \mathrm{O}_{4}$ & 1.17 \\
7 & 13.116 & D-Sucrose (alpha-D-Glucopyranoside, Amerfond, Beet sugar, Cane sugar) & $\mathrm{C}_{12} \mathrm{H}_{22} \mathrm{O}_{11}$ & 23.16 \\
8 & 13.789 & beta-D-Glucopyranose (1,6-anhydro-d-mannosan, Levoglucosan) & $\mathrm{C}_{6} \mathrm{H}_{10} \mathrm{O}_{5}$ & 3.27 \\
9 & 15.077 & 1,6-Anhydro-beta-D-glucofuranose & $\mathrm{C}_{6} \mathrm{H}_{10} \mathrm{O}_{5}$ & 2.19 \\
10 & 15.453 & beta-D-Glucopyranose (beta-Lactose) & $\mathrm{C}_{12} \mathrm{H}_{22} \mathrm{O}_{11}$ & 2.05 \\
11 & 15.899 & beta-D-Fructose (Levulose) & $\mathrm{C}_{6} \mathrm{H}_{12} \mathrm{O}_{6}$ & 2.52 \\
12 & 18.040 & Sorbitol (D-Glucitol, Diakarmon, L-Gulitol, D-1,2,3,4,5,6-hexanehexol, Nivitin) & $\mathrm{C}_{6} \mathrm{H}_{14} \mathrm{O}_{6}$ & 6.68 \\
13 & 23.623 & Hexanedioic acid bis(2-ethylhexyl) ester (Adipic acid bis(2-ethylhexyl) ester, Adipol 2EH, Bisoflex DOA, DOA, & $\mathrm{C}_{22} \mathrm{H}_{42} \mathrm{O}_{4}$ & 0.96 \\
& & Effomoll DOA, Flexol A26, Kodaflex DOA) & & $\mathrm{C}_{10} \mathrm{H}_{38} \mathrm{O}_{4}$ \\
14 & 24.601 & Hexadecanoic acid 2-hydroxy-1-(hydroxymethyl)ethyl ester (2-mono-palmitin, Palmitic acid beta-monoglyceride) & 5.55 \\
15 & 31.913 & Unknown compound & $\mathrm{C}_{12}$ \\
\hline
\end{tabular}

Table 2

The antibacterial effect (radius of growth inhibition zone, $\mathrm{mm}$ ) of extract of $P$. granatum peel on cryogenic strains microorganisms in vitro $(\mathrm{x} \pm \mathrm{SD}, \mathrm{n}=12)$

\begin{tabular}{|c|c|c|c|}
\hline \multirow{2}{*}{ Strains } & \multicolumn{2}{|c|}{ Exposition } & \multirow{2}{*}{ Reference $^{1}$} \\
\hline & 24 hours & 48 hours & \\
\hline Escherichia coli 055 K 59 No. $3912 / 41$ & $11.51 \pm 1.12^{\mathrm{a}}$ & $14.45 \pm 1.35^{\mathrm{a}}$ & $13.62 \pm 0.96^{\mathrm{a}}$ \\
\hline Enterobacter aegorenes 10006 & $6.32 \pm 0.67^{\mathrm{a}}$ & $8.13 \pm 0.92^{\mathrm{ab}}$ & $8.99 \pm 0.93^{b}$ \\
\hline Enterococcus faecalis ATCC 19433 & $0 \pm 0^{\mathrm{a}}$ & $0 \pm 0^{\mathrm{a}}$ & $5.47 \pm 2.03^{\mathrm{b}}$ \\
\hline Proteus vulgaris HX 19 No. 222 & $19.56 \pm 1.78^{\mathrm{a}}$ & $20.78 \pm 2.31^{\mathrm{a}}$ & $2.34 \pm 0.23^{\mathrm{b}}$ \\
\hline Serratia marcescens 1 & $8.78 \pm 0.89^{\mathrm{a}}$ & $10.45 \pm 1.33^{\mathrm{a}}$ & $3.32 \pm 0.19^{b}$ \\
\hline Klebsiella pneumoniae K-56 No. 3534/51 & $8.34 \pm 0.77^{\mathrm{a}}$ & $9.67 \pm 1.22^{\mathrm{a}}$ & $12.09 \pm 2.78^{\mathrm{a}}$ \\
\hline Salmonella typhimurium 144 & $0 \pm 0^{\mathrm{a}}$ & $0 \pm 0^{\mathrm{a}}$ & $0 \pm 0^{\mathrm{a}}$ \\
\hline Staphylococcus aureus ATCC 25923 & $4.31 \pm 0.65^{\mathrm{a}}$ & $7.15 \pm 0.94^{b}$ & $22.40 \pm 2.36^{\mathrm{c}}$ \\
\hline Bacillus cereus ATCC 10702 & $4.89 \pm 0.76^{\mathrm{a}}$ & $7.43 \pm 1.23^{b}$ & $15.60 \pm 1.32^{\mathrm{c}}$ \\
\hline Listeria innocua АТCС 33090 & $14.12 \pm 1.88^{\mathrm{a}}$ & $17.32 \pm 1.87^{\mathrm{a}}$ & $15.40 \pm 1.82^{\mathrm{a}}$ \\
\hline L. ivanovi & $14.67 \pm 1.76^{\mathrm{a}}$ & $16.33 \pm 2.65^{\mathrm{ab}}$ & $20.30 \pm 1.64^{b}$ \\
\hline L. monocytogenes ATCC 19112 & $20.87 \pm 2.14^{\mathrm{a}}$ & $21.89 \pm 1.76^{\mathrm{a}}$ & $14.23 \pm 1.44^{\mathrm{b}}$ \\
\hline Corynebacterium xerosis 1911 & $2.34 \pm 0.23^{\mathrm{a}}$ & $7.15 \pm 0.94^{\mathrm{b}}$ & $25.35 \pm 2.21^{\mathrm{c}}$ \\
\hline Candida albicans & $16.67 \pm 1.77^{\mathrm{a}}$ & $18.56 \pm 2.11^{\mathrm{a}}$ & $2.48 \pm 0.21^{\mathrm{b}}-$ azithromycin; $18.20 \pm 2.35^{\mathrm{a}}-$ amphotericinin \\
\hline
\end{tabular}

Notes: 1 - for bacteria, discs with $15.0 \mu \mathrm{g}$ azithromycin were used as positive control (Valle et al., 2015), and for C. albicans - discs with $15.0 \mu \mathrm{g}$ amphotericinin; different letters indicate the values significantly differing one from another within a line of the Table on the results of comparison using the Tukey test $(\mathrm{P}<0.05)$ with Bonferroni correction.

Moderate resistance of $C$. xerosis to extracts from peel of $P$. granatum: growth inhibition zone ranged $2.34 \mathrm{~mm}(24 \mathrm{~h})$ to $4.81 \mathrm{~mm}$ ( $48 \mathrm{~h}$ of exposition). Susceptibility of C. albicans to extracts from peel of $P$. granatum was observed: after $48 \mathrm{~h}$ of incubation this parameter was higher compared to azithromycin and amphotericinin by 16.08 and $0.36 \mathrm{~mm}$.

Table 2

Mortality of larvae of (\%) Strongyloides papillosus Wedl, 1956 in extracts of $P$. granatum peel in different concentrations

\begin{tabular}{ccc}
\hline \multirow{2}{*}{ Concentration, $\%$} & \multicolumn{2}{c}{ Development stages of S. papillosus larvae } \\
\cline { 2 - 3 } & $\mathrm{L}_{1}-\mathrm{L}_{2}$ & $\mathrm{~L}_{3}$ \\
\hline 0 (control) & $1.6 \pm 0.3$ & 0.0 \\
\hline 1 & $1.7 \pm 0.4$ & 0.0 \\
5 & $4.1 \pm 0.9$ & 0.0 \\
10 & $5.9 \pm 1.4$ & 0.0 \\
15 & $82.1 \pm 16.2$ & $75.8 \pm 9.2$ \\
20 & 100.0 & 100.0 \\
25 & 100.0 & 100.0 \\
\hline
\end{tabular}

Right after the contact with the solutions of $0.5 \%$ and $1.0 \%$ concentrations, the ciliates begun to move rapidly, moving with the front end, and then died, obtaining spherical shape. In concentraton of $0.2 \%$, P. caudatum slowed, maintained shape without any changes, but a large proportion of them died. Further dilution had no effect on the ciliates. For pomegranate extract, $\mathrm{LC}_{50}$ equaled $2.97 \mathrm{~g} / \mathrm{L}$, or $0.3 \%$ concentration. In this product, $\mathrm{LC}_{100}$ was determined at the level of $4.51 \mathrm{~g} / \mathrm{L}$ or around $0.45 \%$.

According to the results of the studies on the impact of $P$. granatum extract on the level of mortality of nematode larvae of $S$. papillosus, parasites of gastrointernal tract of ruminants, the number of dead specimens in $1 \%$ solution on average did not exceed the control. No positive reaction was observed either during use of $5 \%$ and $10 \%$ extract. Notable effect was recorded after affecting the larvae with exposures equaling
$24 \mathrm{~h}$ with $15 \%$ extract of the studied substance. During use of extract in this concentration, over $80 \%$ of the dead individuals were of the first and second stage of the development. Among third stage larvae, mortality of $75 \%$ of specimens was observed. Best results were obtained after using 20-25\% extract of $P$. granatum (Table 2).

\section{Discussion}

Aqueous extracts of henna and pomegranate showed higher antifungal activity as compared to their corresponding ethanolic extracts (Singla et al., 2013). The increase in total aerobic plate counts, $\mathrm{pH}$ and total volatile basic nitrogen values were significantly inhibited in shrimps treated with chitosan coating combined with pomegranate peel extract (Yuan et al., 2015). Ari et al. (2018) report that pomegranate juise had a synergistic effect when used in combination with antibiotics. In vitro, methanolic extract of pomegranate peel caused inhibitory effect to the linear growth of six economically important fungal phytopathogens isolated from different hosts including: Botrytis cinerea, Colletotrichum dematium, Fusarium oxysporum, F. solani, Phoma spp., and Rhizoctonia solani (Mohamad et al., 2015). Potent inhibitory effects of PoP extracts were observed against Bacillus subtilis, Staphylococcus aureus, Pseudomonas aeruginosa, Escherichia coli, Salmonella typhimurium and Aspergillus niger and minimum inhibitory concentration (MIC) was recorded between $0.25-0.89 \mathrm{mg} / \mathrm{mL}$ (Ismail et al., 2016).

After analyzing the results of our research, it was found that the extract of $P$. granatum can compete with azithromycin, a broad-spectrum antibiotic from the macrolide group, whose spectrum of action includes Staphylococcus aureus, S. epidermidis, Streptococcus agalactiae, S. pneumonia, and S. acupuncture, Chlamydia trachomatis, Ch. pneumoniae, Mycobacterium avium complex, Mycoplasma pneumoniae, Ureaplasma 
urealyticum, Treponema pallidum, Borrelia burgdorferi (RodriguezCavallini, 2004). Extract of $P$. granatum can compete with azithromycin by acting on strains of Escherichia coli, Enterobacter aegorenes, Proteus vulgaris, Serratia marcescens, Klebsiella pneumonia, Listeria ivanovi, L. innocua, L. monocytogenes and Candida albicans.

During biotesting with Paramecium caudatum in our experiment, $\mathrm{LC}_{100}$ equaling within $0.1-1.0 \%$ allows the extract of pomegranate to be classified to the third class of toxicity (according to GOST 12.1.007-76 System of standards of labour safety. Toxic substances. Classification and general requirements for safety). Also the obtained results were compared to the calculations of toxicity according to method of Pershyn and Bliss-Prozorovskii (Prozorovskii, 2007): according to Pershyn method $\mathrm{LC}_{50}=2.81 \mathrm{~g} / \mathrm{L}$, and Bliss-Prozorovskii $\mathrm{LC}_{16}=2.32 \mathrm{~g} / \mathrm{L}, \mathrm{LC}_{50}=$ $3.15 \mathrm{~g} / \mathrm{L}, \mathrm{LC}_{84}=3.99 \mathrm{~g} / \mathrm{L}$, i.e. the curve of dependence of lethality corresponds to the graph $\mathrm{y}=1.25+1.19 \cdot \mathrm{x}$. Therefore, the results on activity of extract of pomegranate towards ciliates allow it to be classified as a moderately toxic substance, $\mathrm{LC}_{50}$ ranging $151-5000 \mathrm{mg} / \mathrm{kg}$ (Kotsumbas, 2006). These data coincide with the data obtained for laboratory animals with similar ethanol extracts of pomegranate, differences can be caused by different conditions of obtaining the product from local raw material. Therefore, Satheesh Kumar Bhandary et al. (2013) indicate that $\mathrm{LD}_{50}$ of ethanol extract from fruits and seeds of $P$. granatum in white rats exceeded $2 \mathrm{~g} / \mathrm{kg}$, and Patel (2008) determined that $\mathrm{LD}_{50}$ in extracts of pomegranate fruits for rats and mice exceeds $5 \mathrm{~g} / \mathrm{kg}$ of body weight, level of no-observed-adverse-effect level (NOAEL) was determined as $600 \mathrm{mg} / \mathrm{kg}$ of body weight a day.

The impact of plants and plant-based preparations on the development of helminths in vitro and in vivo was studied by several authors. The experiments were conducted on the impact of alcohol extract of $P$. granatum on the development of cestodes and nematodes. Akhtar \& Riffat (1985) have demonstrated the impact of peel of $P$. granatum on different species of sheep cestodes. During use of $P$. granatum, the intensity of infection of sheep with different species of cestodes decreased. Kalesaraj (1974) proved anthelminth activity in vitro of alcohol extract from peel of $P$. granatum against Ascaris lumbricoides (Linneus, 1758). A number of authors conducted experiments on impact of alcohol extract of $P$. granatum on the development of nematodes of the Strongylida order. Pradhan et al. (1992) observed therapeutic efficiency of $P$. granatum in sheep with Nematodirus. Positive anthelminth effect was observed in vitro. Prakash et al. (1980) determined the effect of alcohol extract of $P$. granatum on inhibition of the development of eggs of Haemonchus contortus (Rudolphi, 1803).

Thus, internal parts (interior walls or mesocarp) of fruits of $P$. granatum can have a significant impact on microbiocenosis of soil, fauna of soil protists and invertebrates. According to the results of previous experiments mass species of insects can die after consuming plant remains not characteristic of their habitat. For example, Opatrum sabulosum (Linnaeus, 1761), a dangerous pest in Steppe and Forest-Steppe zone of Eurasia, cannot consume plants of certain species (Brygadyrenko \& Nazimov, 2014, 2015). Volatile compounds present in some species of plants can scare off or lure insects (Martynov et al., 2019). Plant remains on the soil surface change horizontal structure of communities of invertebrates (Faly \& Brygadyrenko, 2014), which can occur directly during consumption of food, as well as indirectly by changes in species composition of biocenosis in certain parts. A complex study of chemical composition and effect on different groups of living organisms would allow determination of what are still hidden interrelations in natural ecosystems, and for the researched substances to be used with minimum damage to biodiversity.

\section{Conclusion}

The experiment in vitro revealed a positive antibacterial effect from the use of extracts of $P$. granatum on strains of Enterobacteriaceae microorganisms: E. coli, E. aegorenes, P. vulgaris, S. marcescens, $K$. pneumonia; Listeriaceae: L. ivanovi, L. innocua, L. monocytogenes; and Saccharomycetaceae: C. albicans. We consider it possible to recommend the investigated extracts of $P$. granatum for further research in the fight against polyresistant strains of the above-mentioned microorgan- isms. Ethanol extract of pomegranate belongs to moderately toxic substances during biotesting on $P$. caudatum, $\mathrm{LC}_{50}$ corresponds to $0.3 \%$ concentration of the preparation. Nematode larvae of S. papillosus die during processing with $20 \%$ extracts of $P$. granatum peel.

This work was supported by the Ministry of Education and Science of Ukraine (grant 0119U100724).

\section{References}

Akhtar, M. S., \& Riffat, S. (1985). Evaluation of Melia azedarach Linn. seeds (Bakain) and piperazine against Ascaridia galli infection in chickens. Pakistan Veterinary Journal, 5, 34-37.

Abbasi, H., Rezaei, K., \& Rashidi, L. (2007). Extraction of essential oils from the seeds of pomegranate using organic solvents and supercritical $\mathrm{CO}_{2}$. Journal of the American Oil Chemists' Society, 85(1), 83-89.

Abbey, M., Nestel, P. J., \& Baghurst, P. A. (1993). Antioxidant vitamins and lowdensity-lipoprotein oxidation. The American Journal of Clinical Nutrition, 58(4), 525-532.

Afaq, F., Saleem, M., Krueger, C. G., Reed, J. D., \& Mukhtar, H. (2004). Anthocyanin- and hydrolyzable tannin-rich pomegranate fruit extract modulates MAPK and NF-B pathways and inhibits skin tumorigenesis in CD-1 mice. International Journal of Cancer, 113(3), 423-433.

Albrecht, M., Jiang, W., Kumi-Diaka, J., Lansky, E. P., Gommersall, L. M., Patel, A., Mansel, R. E., Neeman, I., Geldof, A. A., \& Campbell, M. J. (2004). Pomegranate extracts potently suppress proliferation, xenograft growth, and invasion of human prostate cancer cells. Journal of Medicinal Food, 7(3), 274-283.

Ari, M., \& Erbil, N. (2018). Antibacterial effect of purchased pomegranate juice and its sinergistic effect with some antibiotics. Journal of the Institute of Science and Technology, 2018, 131-135.

Ashoush, I. S., El-Batawy, O. I., \& El-Shourbagy, G. A. (2013). Antioxidant activity and hepatoprotective effect of pomegranate peel and whey powders in rats. Annals of Agricultural Sciences, 58(1), 27-32.

Aviram, M., Dornfeld, L., Rosenblat, M., Volkova, N., Kaplan, M., Coleman, R., Hayek, T., Presser, D., \& Fuhrman, B. (2000). Pomegranate juice consumption reduces oxidative stress, atherogenic modifications to $\mathrm{LDL}$, and platelet aggregation: Studies in humans and in atherosclerotic apolipoprotein E-deficient mice. The American Journal of Clinical Nutrition, 71(5), 1062-1076.

Aviram, M., Rosenblat, M., Gaitini, D., Nitecki, S., Hoffman, A., Dornfeld, L., Volkova, N., Presser, D., Attias, J., Liker, H., \& Hayek, T. (2004). Pomegranate juice consumption for 3 years by patients with carotid artery stenosis reduces common carotid intima-media thickness, blood pressure and LDL oxidation. Clinical Nutrition, 23(3), 423-433.

Aviram, M., Volkova, N., Coleman, R., Dreher, M., Reddy, M. K., Ferreira, D., \& Rosenblat, M. (2008). Pomegranate phenolics from the peels, arils, and flowers are antiatherogenic: Studies in vivo in atherosclerotic apolipoprotein edeficient $\left(\mathrm{E}_{0}\right)$ mice and in vitro in cultured macrophages and lipoproteins. Journal of Agricultural and Food Chemistry, 56(3), 1148-1157.

Azadzoi, K. M., Schulman, R. N., Aviram, M., \& Siroky, M. B. (2005). Oxidative stress in arteriogenic erectile dysfunction: Prophylactic role of antioxidants. Journal of Urology, 174(1), 386-393.

Basu, A., \& Penugonda, K. (2009). Pomegranate juice: A heart-healthy fruit juice. Nutrition Reviews, 67(1), 49-56.

Bhandary, S. K., Kumari, S., Bhat, V. S., Sharmila, K., \& Bekal, M. P. (2012). Preliminary phytochemical screening of various extracts of Punica granatum peel, whole fruit and seeds. Journal Health Sciences, 2, 35-38.

Boyko, A. A., \& Brygadyrenko, V. V. (2016). Influence of water infusion of medicinal plants on larvae of Strongyloides papillosus (Nematoda, Strongyloididae). Visnyk of Dnipropetrovsk University, Biology, Ecology, 24(2), 519-525.

Brygadyrenko, V. V., \& Nazimov, S. S. (2014). Nutrition of Opatrum sabulosum (Coleoptera, Tenebrionidae) when fed on leaves of trees, shrubs and liana plants in the conditions of a laboratory experiment. Baltic Journal of Coleopterology, 14(1), 59-72.

Brygadyrenko, V. V., \& Nazimov, S. S. (2015). Trophic relations of Opatrum sabulosum (Coleoptera, Tenebrionidae) with leaves of cultivated and uncultivated species of herbaceous plants under laboratory conditions. Zookeys, 481, 57-68.

Burke, J. M., Wells, A., Casey, P., \& Kaplan, R. M. (2009). Herbal dewormer fails to control gastrointestinal nematodes in goats. Veterinary Parasitology, $160,168-170$.

Cáceres, A., Girón, L. M., Alvarado, S. R., \& Torres, M. F. (1987). Screening of antimicrobial activity of plants popularly used in guatemala for the treatment of dermatomucosal diseases. Journal of Ethnopharmacology, 20(3), 223-237.

Caligiani, A., Bonzanini, F., Palla, G., Cirlini, M., \& Bruni, R. (2010). Characterization of a potential nutraceutical ingredient: Pomegranate (Punica granatum L.) seed oil unsaponifiable fraction. Plant Foods for Human Nutrition, 65(3), 277-283. 
Chan, K. W., \& Ismail, M. (2009). Supercritical carbon dioxide fluid extraction of Hibiscus cannabinus L. seed oil: A potential solvent-free and high antioxidative edible oil. Food Chemistry, 114(3), 970-975.

Dadashi, S., Mousazadeh, M., Emam-Djomeh, Z., \& Mousavi, S. M. (2013). Pomegranate (Punica granatum L.) seed: A comparative study on biochemical composition and oil physicochemical characteristics. International Journal of Advanced Biological and Biomedical Research, 1, 351-363.

Davidson, M. H., Maki, K. C., Dicklin, M. R., Feinstein, S. B., Witchger, M., Bell, M., McGuire, D. K., Provost, J.-C., Liker, H., \& Aviram, M. (2009). Effects of consumption of pomegranate juice on carotid intima-media thickness in men and women at moderate risk for coronary heart disease. The American Journal of Cardiology, 104(7), 936-942.

De Nigris, F., Williams-Ignarro, S., Botti, C., Sica, V., Ignarro, L. J., \& Napoli, C. (2006). Pomegranate juice reduces oxidized low-density lipoprotein downregulation of endothelial nitric oxide synthase in human coronary endothelial cells. Nitric Oxide, 15(3), 259-263.

El-Nemr, S. E., Ismail, I. A., \& Ragab, M. (1990). Chemical composition of juice and seeds of pomegranate fruit. Food / Nahrung, 34(7), 601-606.

Esterbauer, H., Gebicki, J., Puhl, H., \& Jürgens, G. (1992). The role of lipid peroxidation and antioxidants in oxidative modification of LDL. Free Radical Biology and Medicine, 13(4), 341-390.

Fadavi, A., Barzegar, M., \& Hossein Azizi, M. (2006). Determination of fatty acids and total lipid content in oilseed of 25 pomegranates varieties grown in Iran. Journal of Food Composition and Analysis, 19, 676-680.

Faly, L. I., \& Brygadyrenko, V. V. (2014). Patterns in the horizontal structure of litter invertebrate communities in windbreak plantations in the steppe zone of the Ukraine. Journal of Plant Protection Research, 54(4), 414 420.

Ferreira, J. F. S., Peaden, P., \& Keiser, J. (2011). In vitro trematocidal effects of crude alcoholic extracts of Artemisia annua, A. absinthium, Asimina triloba and Fumaria officinalis. Parasitology Research, 109(6), 1585-1592.

Fuhrman, B., \& Aviram, M. (2001). Flavonoids protect LDL from oxidation and attenuate atherosclerosis. Current Opinion in Lipidology, 12(1), 41-48.

Fuhrman, B., Volkova, N., \& Aviram, M. (2005). Pomegranate juice inhibits oxidized LDL uptake and cholesterol biosynthesis in macrophages. The Journal of Nutritional Biochemistry, 16(9), 570-576

Fuhrman, B., Volkova, N., \& Aviram, M. (2010). Pomegranate juice polyphenols increase recombinant paraoxonase-1 binding to high-density lipoprotein: Studies in vitro and in diabetic patients. Nutrition, 26(4), 359-366.

Gil, M. I., Tomás-Barberán, F. A., Hess-Pierce, B., Holcroft, D. M., \& Kader, A. A (2000). Antioxidant activity of pomegranate juice and its relationship with phenolic composition and processing. Journal of Agricultural and Food Chemistry, 48(10), 4581-4589.

Guo, C., Wei, J., Yang, J., Xu, J., Pang, W., \& Jiang, Y. (2008). Pomegranate juice is potentially better than apple juice in improving antioxidant function in elderly subjects. Nutrition Research, 28(2), 72-77.

Haber, S. L., Joy, J. K., \& Largent, R. (2011). Antioxidant and antiatherogenic effects of pomegranate. American Journal of Health-System Pharmacy, 68(14), 1302-1305

Habibnia, M., Ghavami, M., Ansaripourc, M., \& Vosough, S. (2012). Chemical evaluation of oils extracted from five different varieties of Iranian pomegranate seeds. Journal of Food Biosciences and Technology, 2, 35-40.

Holland, D., Hatib, K., \& Bar-Ya'akov, I. (2009). Pomegranate: Botany, horticulture, breeding. Horticultural Reviews, 127-191.

Huang, T. H.-W., Peng, G., Kota, B. P., Li, G. Q., Yamahara, J., Roufogalis, B. D., \& Li, Y. (2005). Pomegranate flower improves cardiac lipid metabolism in a diabetic rat model: Role of lowering circulating lipids. British Journal of Pharmacology, 145(6), 767-774.

Ignarro, L. J., Byrns, R. E., Sumi, D., de Nigris, F., \& Napoli, C. (2006). Pomegranate juice protects nitric oxide against oxidative destruction and enhances the biological actions of nitric oxide. Nitric Oxide, 15(2), 93-102.

Ismail, T., Akhtar, S., Sestili, P., Riaz, M., Ismail, A., \& Labbe, R. G. (2016) Antioxidant, antimicrobial and urease inhibitory activities of phenolics-rich pomegranate peel hydro-alcoholic extracts. Journal of Food Biochemistry, 40(4), 550-558

Jahromi, S. B., Pourshafie, M. R., Mirabzadeh, E., Tavasoli, A., Katiraee, F., Mostafavi, E., \& Abbasian, S. (2015). Punica granatum peel extract toxicity in mice. Jundishapur Journal of Natural Pharmaceutical Products, 10(4), e23770.

Faisi, J., Fattahi, A., Raffel, N., Hoffmann, I., Beckmann, M. W., Schrauder, M., Dittrich, R., \& Löhberg, C. (2018). Effects of pomegranate seed oil and fermented juice polyphenols fraction in different solvents on copper-induced LDL oxidation. CyTA - Journal of Food, 16(1), 429-437.

Ji, S., Fattahi, A., Raffel, N., Hoffmann, I., Beckmann, M. W., Dittrich, R., \& Schrauder, M. (2017). Antioxidant effect of aqueous extract of four plants with therapeutic potential on gynecological diseases; Semen persicae, Leonurus cardiaca, Hedyotis diffusa, and Curcuma zedoaria. European Journal of Medical Research, 22, 50.
Kalesaraj, R. (1974). Screening of some indigenous plants for anthelmintic action against human Ascaris lumbricoides. Part II. Indian Journal of Physiology and Pharmacology, 19, 47-49.

Kaur, G., Jabbar, Z., Athar, M., \& Alam, M. S. (2006). Punica granatum (pomegranate) flower extract possesses potent antioxidant activity and abrogates Fe-NTA induced hepatotoxicity in mice. Food and Chemical Toxicology, 44(7), 984-993.

Khateeb, J., Gantman, A., Kreitenberg, A. J., Aviram, M., \& Fuhrman, B. (2010). Paraoxonase 1 (PON1) expression in hepatocytes is upregulated by pomegranate polyphenols: A role for PPAR- $\gamma$ pathway. Atherosclerosis, 208(1), $119-125$.

Kim, N. D., Mehta, R., Yu, W., Neeman, I., Livney, T., Amichay, A., Poirier, D., Nicholls, P., Kirby, A., Jiang, W., Mansel, R., Ramachandran, C., Rabi, T., Kaplan, B., \& Lansky, E. (2002). Chemopreventive and adjuvant therapeutic potential of pomegranate (Punica granatum) for human breast cancer. Breast Cancer Research and Treatment, 71(3), 203-217.

Kohno, H., Suzuki, R., Yasui, Y., Hosokawa, M., Miyashita, K., \& Tanaka, T. (2004). Pomegranate seed oil rich in conjugated linolenic acid suppresses chemically induced colon carcinogenesis in rats. Cancer Science, 95(6), 481-486.

Konishi, Y., Hitomi, Y., \& Yoshioka, E. (2004). Intestinal absorption ofp-coumaric and gallic acids in rats after oral administration. Journal of Agricultural and Food Chemistry, 52(9), 2527-2532.

Kotsumbas, I. Y., Malyk, O. G., \& Paterega, I. P. (2006). Doklinichni doslidzhennya veterinarnih likarskih zasobiv [Preclinical studies of veterinary medicinal products]. Triada Plus, Lviv (in Ukrainian).

Lansky, E. P., \& Newman, R. A. (2007). Punica granatum (pomegranate) and its potential for prevention and treatment of inflammation and cancer. Journal of Ethnopharmacology, 109(2), 177-206.

Liu, B. Li, W. Hu, L. \& Zhao, J. (2012). Mild alkaline hydrolysis is an efficient and low-cost method for improving the free phenolic content and health benefit of pomegranate peel extract. Journal of Food Processing and Preservation, 37(5), 694-700

Liu, G., Xu, X., Gong, Y., He, L., \& Gao, Y. (2012). Effects of supercritical $\mathrm{CO}_{2}$ extraction parameters on chemical composition and free radical-scavenging activity of pomegranate (Punica granatum L.) seed oil. Food and Bioproducts Processing, 90(3), 573-578

Liu, G., Xu, X., Hao, Q., \& Gao, Y. (2009). Supercritical $\mathrm{CO}_{2}$ extraction optimization of pomegranate (Punica granatum L.) seed oil using response surface methodology. LWT - Food Science and Technology, 42(9), 1491-1495.

Liu, W., Fu, Y.-J., Zu, Y.-G., Tong, M.-H., Wu, N., Liu, X.-L., \& Zhang, S (2009). Supercritical carbon dioxide extraction of seed oil from Opuntia dillenii Haw. and its antioxidant activity. Food Chemistry, 114(1), 334-339.

Lu, C. D., Gangyi, X., \& Kawas, J. R. (2010). Organic goat production, processing and marketing: Opportunities, challenges and outlook. Small Ruminant Research, 89(2-3), 102-109.

Mahajan, D., Bhat, Z. F., \& Kumar, S. (2015). Pomegranate (Punica granatum) rind extract as a novel preservative in cheese. Food Bioscience, 12, 47-53.

Martynov, V. O., Titov, O. G., Kolombar, T. M., \& Brygadyrenko, V. V. (2019) Influence of essential oils of plants on the migration activity of Tribolium confusum (Coleoptera, Tenebrionidae). Biosystems Diversity, 27(2), 177-185.

Mehdi Talebi, S., Ghorbani Nohooji, M., Yarmohammadi, M., Azizi, N., \& Matsyura, A. (2018). Trichomes morphology and density analysis in some "Nepeta" species of Iran. Mediterranean Botany, 39(1), 51-62.

Mehru, N., Rathinam, X., Subramaniam, S., Aiyalu, R., Sreenivasan, S., \& Reenivasan, S. (2008). Antimicrobial activity and toxicity of Punica granatum L., peel. Journal of Applied Biological Sciences, 2(3), 57-59.

Mohamad, T., \& Khalil, A. (2015). Effect of agriculture waste: Pomegranate (Punica granatum L.) fruits peel on some important phytopathogenic fung and control of tomato damping-off. Journal of Applied Life Sciences International, 3(3), 103-113.

Mori-Okamoto, J., Otawara-Hamamoto, Y., Yamato, H., \& Yoshimura, H. (2004). Pomegranate extract improves a depressive state and bone properties in menopausal syndrome model ovariectomized mice. Journal of Ethnopharmacology, 92(1), 93-101.

Mphahlele, R. R., Fawole, O. A., Mokwena, L. M., \& Opara, U. L. (2016). Effect of extraction method on chemical, volatile composition and antioxidant properties of pomegranate juice. South African Journal of Botany, 103, 135-144.

Nasiri, E., Hesari, J., Shekarforoush, S., \& Kooshesh, S. (2016). Effect of aqueous extract of myrtle leaves (Myrtus communis) on quality changes of farmed gutted rainbow trout (Oncorhynchus mykiss) during chilled $\left(4 \pm 1{ }^{\circ} \mathrm{C}\right)$ storage. Iranian Scientific Fisheries Journal, 25, 1-14.

Naveena, B. M., Sen, A. R., Vaithiyanathan, S., Babji, Y., \& Kondaiah, N. (2008). Comparative efficacy of pomegranate juice, pomegranate rind powder extract and BHT as antioxidants in cooked chicken patties. Meat Science, 80(4), 1304-1308.

Naveena, B., Sen, A., Vaithiyanathan, S., Muthukumar, M., \& Babji, Y. (2007) Microwave cooking properties of chicken patties containing honey and vitamin-C. Journal of Food Science and Technology, 44, 505-508. 
Negi, P. S., Jayaprakasha, G. K., \& Jena, B. S. (2003). Antioxidant and antimutagenic activities of pomegranate peel extracts. Food Chemistry, 80(3), 393-397.

Ono, N. N., Britton, M. T., Fass, J. N., Nicolet, C. M., Lin, D., \& Tian, L. (2011). Exploring the transcriptome landscape of pomegranate fruit peel for natural product biosynthetic gene and SSR marker discovery. Journal of Integrative Plant Biology, 53(10), 800-813.

Orhan, I., Aydin, A., Çölkesen, A., Sener, B., \& Isimer, A. I. (2003). Free radical scavenging activities of some edible fruit seeds. Pharmaceutical Biology, 41(3), 163-165.

Özgül-Yücel, S. (2005). Determination of conjugated linolenic acid content of selected oil seeds grown in Turkey. Journal of the American Oil Chemists' Society, 82(12), 893-897.

Patel, C., Dadhaniya, P., Hingorani, L., \& Soni, M. G. (2008). Safety assessment of pomegranate fruit extract: Acute and subchronic toxicity studies. Food and Chemical Toxicology, 46(8), 2728-2735.

Pirillo, A., Norata, G. D., \& Catapano, A. L. (2013). LOX-1, OxLDL, and atherosclerosis. Mediators of Inflammation, 2013, 1-12.

Pradhan, K. D., Thakur, D. K., \& Sudhan, N. A. (1993). Therapeutic efficacy of Punica granatum and $C$. maxima against clinical cases of nematodiasis in calves. Indian Journal of Indigenous Medicines, 9, 53-54.

Singhal, K. C. (1983). Anthelmintic activity of Punica granatum and Artemisia siversiana against experimental infections in mice. Indian Journal of Pharmacology, 15(2), 119-122.

Prozorovskii, V. B. (2007). Statisticheskaya obrabotka rezul'tatov farmakologicheskikh issledovanij [Statistic processing of data of pharmacological investigations]. Psikhofarmakologiya i Biologicheskaya Narkologiya, 7(3-4), 2090-2120 (in Russian)

Rahimi, H. R., Arastoo, M., \& Ostad, S. N. (2012). A comprehensive review of Punica granatum (pomegranate) properties in toxicological, pharmacological, cellular and molecular biology researches. Iranian Journal of Pharmaceutical Research, 11, 385-400.

Rahmann, G., \& Seip, H. (2006). Alternative strategies to prevent and control endoparasite diseases in organic sheep and goat farming systems. Ressortforschung für den Ökologischen Landbau, 2006, 49-90.

Rosenblat, M., \& Aviram, M. (2006). Antioxidative properties of pomegranate: In vitro studies. In: Seeram, N. P., Schulman, R. N., \& Heber, D. (Eds.). Pomegranates: Ancient roots to modern medicine. Pp. 31-43.

Sandhya, S., Khamrui, K., Prasad, W., \& Kumar, M. C. T. (2018). Preparation of pomegranate peel extract powder and evaluation of its effect on functiona properties and shelf life of curd. Lebensmittel-Wissenschaft und Technologie, $92,416-421$

Bhandary, S. K. B., Sharmila, K. P, Suchetha Kumari, N., \& Vadisha Bhat, S. (2013). Acute and subacute toxicity study of the ethanol extracts of Punica granatum (LINN) whole fruit and seeds and synthetic ellagic acid in swiss albino mice. Asian Journal of Pharmaceutical and Clinical Research, 6(Suppl. 4), 192-198.

Saxena, A., \& Vikram, N. K. (2004). Role of selected Indian plants in management of type 2 diabetes: A review. The Journal of Alternative and Complementary Medicine, 10,369-378.

Schubert, S. Y., Lansky, E. P., \& Neeman, I. (1999). Antioxidant and eicosanoid enzyme inhibition properties of pomegranate seed oil and fermented juice flavonoids. Journal of Ethnopharmacology, 66(1), 11-17.

Seeram, N., Adams, L., Henning, S., Niu, Y., Zhang, Y., Nair, M., \& Heber, D. (2005). In vitro antiproliferative, apoptotic and antioxidant activities of punicalagin, ellagic acid and a total pomegranate tannin extract are enhanced in combination with other polyphenols as found in pomegranate juice. The Journal of Nutritional Biochemistry, 16(6), 360-367.

Seeram, N. P., Aviram, M., Zhang, Y., Henning, S. M., Feng, L., Dreher, M., \& Heber, D. (2008). Comparison of antioxidant potency of commonly consumed polyphenol-rich beverages in the United States. Journal of Agricultural and Food Chemistry, 56(4), 1415-1422.

Seeram, N. P., Lee, R., \& Heber, D. (2004). Bioavailability of ellagic acid in human plasma after consumption of ellagitannins from pomegranate (Punica granatum L. ) juice. Clinica Chimica Acta, 348, 63-68.
Setiadhi, R., Sufiawati, I., Zakiawati, D., Nur'aeny, N., Hidayat, W., \& Firman, D. R (2017). Evaluation of antibacterial activity and acute toxicity of pomegranate (Punica granatum L.) seed ethanolic extracts in swiss webster mice. Journal of Dentomaxillofacial Science, 2(2), 119-123.

Sezer, E. D., Akçay, Y. D., İlanbey, B., Yıldırım, H. K., \& Sözmen, E. Y. (2007) Pomegranate wine has greater protection capacity than red wine on lowdensity lipoprotein oxidation. Journal of Medicinal Food, 10(2), 371-374.

Shahrzad, S., \& Bitsch, I. (1998). Determination of gallic acid and its metabolites in human plasma and urine by high-performance liquid chromatography. Journal of Chromatography B: Biomedical Sciences and Applications, 705(1), 87-95.

Singh, R. P., Chidambara Murthy, K. N., \& Jayaprakasha, G. K. (2002). Studies on the antioxidant activity of pomegranate (Punica granatum) peel and seed extracts using in vitro models. Journal of Agricultural and Food Chemistry, $50(1), 81-86$

Singla, S., Gupta, R., Puri, A., Bhardawaj, V. S., \& Roy, S. (2013). Comparison o anticandidal activity of Punica granatum (pomegranate) and Lawsonia in ermis (Henna leaves): An in-vitro study. International Journal of Dental Research, 1(1), 8-13.

Nuamsetti, T., Dechayuenyong, P., \& Tantipaibulvut, S. (2012). Antibacterial activity of pomegranate fruit peels and arils. Science Asia, 38(3), 319-322.

Topuz, O. K., Yerlikaya, P., Ucak, I., Gumus, B., \& Büyükbenli, H. A. (2014). Effects of olive oil and olive oil - pomegranate juice sauces on chemical, oxidative and sensorial quality of marinated anchovy. Food Chemistry, 154, 63-70.

Turgut, S. S., Soyer, A., \& Işıçç, F. (2016). Effect of pomegranate peel extract on lipid and protein oxidation in beef meatballs during refrigerated storage. Meat Science, 116, 126-132.

Ünalan, U., Dalgaard, P., \& Korel, F. (2011). Effect of pomegranate (Punica granutum) and rosemary (Rosmarinus officinalis) extracts on shelf-life for chilled Greenland halibut (Reinhardtius hippoglossoides) fillets in modified atmosphere packaging at $2{ }^{\circ} \mathrm{C}$. Paper presented at the International Food Congress Novel Approaches in Food Industry. Izmir, Turkey.

Vaithiyanathan, S., Naveena, B. M., Muthukumar, M., Girish, P. S., \& Kondaiah, N. (2011). Effect of dipping in pomegranate (Punica granatum) fruit juice phenolic solution on the shelf life of chicken meat under refrigerated storage $\left(4^{\circ} \mathrm{C}\right)$. Meat Science, 88(3), 409-414.

Viuda-Martos, M., Ruiz-Navajas, Y., Fernández-López, J., Sendra, E., SayasBarberá, E., \& Pérez-Álvarez, J. A. (2011). Antioxidant properties of pomegranate (Punica granatum L.) bagasses obtained as co-product in the juice extraction. Food Research International, 44(5), 1217-1223.

Yamasaki, M., Kitagawa, T., Koyanagi, N., Chujo, H., Maeda, H., KohnoMurase, J., Imamura, J., Tachibana, H., \& Yamada, K. (2006). Dietary effect of pomegranate seed oil on immune function and lipid metabolism in mice. Nutrition, 22(1), 54-59.

Yuan, G., Lv, H., Tang, W., Zhang, X., \& Sun, H. (2016). Effect of chitosan coating combined with pomegranate peel extract on the quality of Pacific white shrimp during iced storage. Food Control, 59, 818-823.

Zahin, M., Aqil, F., \& Ahmad, I. (2010). Broad spectrum antimutagenic activity of antioxidant active fraction of Punica granatum L. peel extracts. Mutation Research/Genetic Toxicology and Environmental Mutagenesis, 703(2), 99-107.

Zajac, A. M., \& Conboy, G. A. (Eds.). (2011). Veterinary clinical parasitology. 8th ed. John Wiley and Sons, London.

Zazharskyi, V. V., Davydenko, P. O., Kulishenko, O. M., Borovik, I. V., \& Brygadyrenko, V. V. (2019). Antimicrobial activity of 50 plant extracts. Biosystems Diversity, 27(2), 163-169.

Zazharskyi, V. V., Davydenko, P., Kulishenko, O., Chumak, V., Kryvaya, A., Biben, I. A., Tishkina, N. M., Borovik, I., Boyko, O. O., \& Brygadyrenko, V. V. (2018). Bactericidal, protistocidal and nematodicidal properties of mixtures of alkyldimethylbenzyl ammonium chloride, didecyldimethyl ammonium chloride, glutaraldehyde and formaldehyde. Regulatory Mechanisms in Biosystems, 9(4), 540-545.

Zhang, H., Chen, H., Yang, D., Chen, W., \& Ying, X. (2014). In situ intestinal absorption of ellagic acid in rats. Chinese Journal of Hospital Pharmacy, 14, 008. 